\section{Autotransplantation and Homotransplantation of Thyroid Gland in the Hamster Cheek Pouch}

ExPERIMENTAL transplantation of the thyroid gland has been widely investigated ${ }^{1,2}$. As a rule autotransplantation of the adult thyroid is easily attained, but positive results with homotransplantation in laboratory animals (mammals) are sometimes achieved only after additional treatment with corticosteroids $s^{3,4}$ or after implantation in the anterior lye chamber ${ }^{5,6}$, brain or, especially in the case of the guinea-pig 7 , in the testes.

In 1951, Lutz et al. ${ }^{8}$ first used the hamster cheek pouch for transplantation of tumours. The cheek pouch is a favourable immunologically tolerant sive not only for homo and heterotransplantation of tumours, but also for such normal tissues as skin?.

Here we report the survival of thyroid tissue implanted in the cheek pouch. This indicates the acceptability at this site of a highly specialized organ.

Fifty-eight male and female non-inbred Syrian hamsters (Mesocricetus auratus Waterhouse, 1839) were used. The donors and recipients were of the same sex and about 3 months old. Table I shows the experimental conditions and the results. The cheek pouches of the animals with transplants were checked weekly, and the animals were killed between the forty-fifth and ninety-third days after transplantation. Transplants were only considered to have survived if certain features were present: viable transplants are commonly reddish and surrounded by a set of vessels. They have a typical appearance under the microscope (Fig. 1) and neither degenerative parenchymal changes nor inflammatory reactions are evident.

Table 1. EXPERIMENTAL GROUPS AND RESULTS AETER TRANSPLANTATION OF A HALF THYROID GLAND IN CHEEK POUCH OF THE SYRIAN HAMSTER

\begin{tabular}{|c|c|c|c|c|c|}
\hline \multirow[t]{2}{*}{ Group } & \multirow{2}{*}{$\begin{array}{c}\text { No. of } \\
\text { animals }\end{array}$} & \multirow{2}{*}{$\begin{array}{l}\text { Treatment before } \\
\text { transplantation }\end{array}$} & \multirow{2}{*}{$\begin{array}{l}\text { Mode of } \\
\text { trans- } \\
\text { plantation }\end{array}$} & \multicolumn{2}{|c|}{ No. of takes } \\
\hline & & & & Positive & Negative \\
\hline I & 13 & Thyroidectomy & auto & 12 & 1 \\
\hline II & 16 & $\begin{array}{l}\text { Thyroidectomy (surgical } \\
\text { or after } 500 \mu \mathrm{c} .^{131} \mathrm{I}\end{array}$ & & & \\
\hline III & 19 & $\begin{array}{l}\text { treatment) } \\
\text { Non-treated }\end{array}$ & $\begin{array}{l}\text { homo } \\
\text { homo }\end{array}$ & $\begin{array}{r}13 \\
4\end{array}$ & $\begin{array}{r}3 \\
15\end{array}$ \\
\hline
\end{tabular}

The follicles of the transplants from groups I and II were smaller than those of group III, while in the normal gland in situ the larger follicles were distributed at the periphery. The cells of the first two groups were cuboidal or cylindrical but in group III they were lower. The size and appearance of the follicles and cells depend to some extent on the

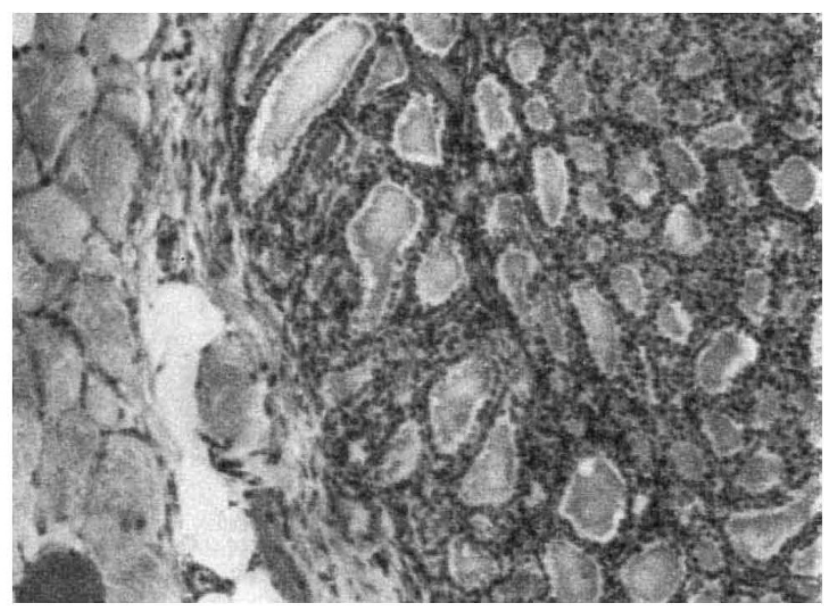

Fig. 1. Microseopic structure of a gland 45 days after homotransplantation. (Haematoxylin and eosin, $x c .40$.)

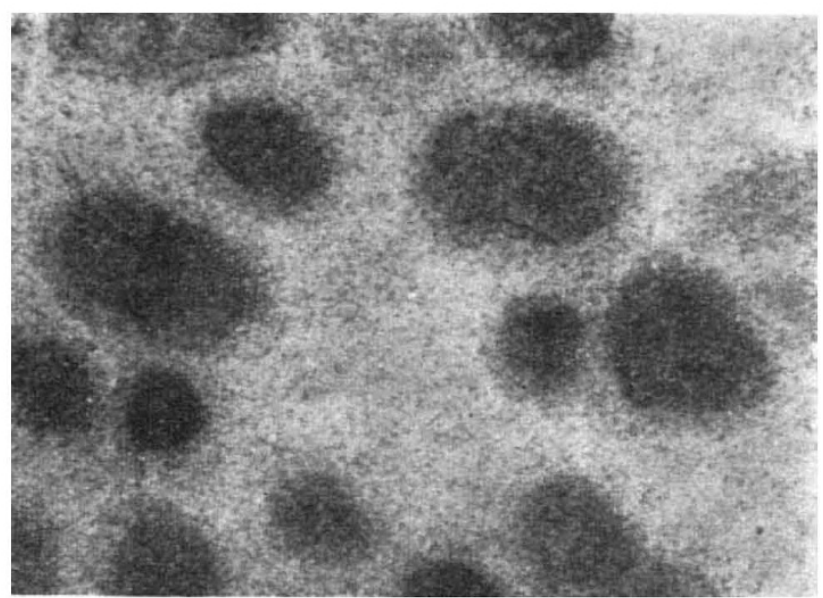

Fig. 2. Autoradiograph from the same gland ( $\times c .70)$.

mechanical pressure exerted by walls of the pouch. A colloid was abundantly present in the follicles from group III, while in groups I and II it was not homogeneous after staining with eosin and periodic acid-Schiff, and many vacuoles were visible at the internal cell apex. The nuclei of the cells were dark and had a coarse chromatin network. About 10-20 per cent of the follicular and interfollicular cells have a clearer cytoplasm and nucleus.

We thyroidectomized some of the animals from group III several days before killing them in order to verify that pituitary extract stimulated the transplants. It was found that the latter are more like the transplants of groups I and II than others.

The animals examined had been injected intraperitoneally with $2 \mu c$. of ${ }^{131} \mathrm{I}$ sodium iodide $6 \mathrm{~h}$ before they were killed. After fixation paraffin slides of their thyroid glands were mounted on strips of Kodak ' $A K 10$ ' stripping films.

Under the experimental conditions used, inorganic iodine-131 was taken up only by the tissues from groups I and II, that is, in the animals deprived of thyroids in situ. Accumulation of radioactive iodine was high and irregular in different follicles (Fig. 2).

These results show that the cheek pouch of the Syrian hamster is a convenient site for thyroid transplantation. A much better survival of homotransplants was observed in thyroidectomized animals. This supports Halstead's views ${ }^{10}$, which have been contested in recent years by some authors ${ }^{11}$.

\section{Ivan Chernozemski} K. Christov

Section of Cancerogenesis and Pathology,

Oncological Research Institute,

Sofia, Bulgaria.

Received March 9, 1967 .

${ }^{1}$ Krohn, P. L., Transplantation of Tissues, 442 (Williams and Wilkins, Baltimore, 1959)

${ }^{2}$ Brooks, J. R., Endocrine Tissue Transplantation (Charles Thomas, Springfield, Iliinois, 1962). 3 Devenyl, T., Czenkar, B., and Endes, P., Acta Morph. Acad. Sci. Hung., 8 ,
39 (1958).

'Woodruff, M. F. A., J. Endocrinol., 11, 1 (1954).

Woodruff, M. F. A., and Woodruff, H. G., Phil. Trans. Roy. Soc., B, 234, $559(1950)$.

- Bredikhin, T. F., Bull. Exp. Biol. Med., 53, 92 (1962).

'Aron, M., Grons, C., Petrovic, A., and Gegaceff, C., C. R. Soc. Biol. 149, 407 (1955). Fabre, M., Asch, L., and Maresceux, J., C. R. Soc.

${ }^{8}$ Lutz, B. H., Fulton, G. P., and Patt, D. J., Cancer Res, 11, 64 (1951).

${ }^{9}$ Billingham, R. E., and Silvers, W. K., Ciba Foundation Symposium on Transplantation, 90 (J. and A. Churchill, London, 1962).

${ }^{10}$ Halstead, W. S., J. Exp. Med.,11, 175 (1909).

${ }^{11}$ Dempster, W. J., and Doniach, L., Arch. Intern. Pharmacodyn., 101, 398 (1955). 